tohoto konceptu v ruském kognitivním obrazu světa. Stat Stanislava Alexandroviče Rylova (Ústav filologie a žurnalistiky, Univerzita Lobačevského, Nižnij Novgorod) Синтактический синкретизм как структурно-семантическая категория (на фоне сопоставительной славянской синтактологии) je př́spěvkem k bádání v oblasti lingvistického synkretismu. Autor definuje sémantické základy syntaktického synkretismu a vyčleňuje kategoriální příznaky v plánu obsahovém i v plánu výrazovém. Předmětem zkoumání jsou synkretické konstrukce v ruském a českém jazyce v pohledu diachronickém i synchronickém, prričemž základem pro porovnávání je plán výrazový. Celý sborník př́iznačně uzavírá stat Zdeňky Vychodilové (FF UP, Olomouc) s názvem Profesor Stanislav Žaža a česká a ruská syntaktická tradice. Předmětem tohoto príspěvku je přehled odlišností v chápání vybraných syntaktických jevů v ruské lingvistické tradici v porovnání s lingvistickou tradicí českou. Autorka se soustředuje na popis odlišností v pojetí větných členů a analyzuje doplněk, sémantický subjekt, objekt a přívlastek. Připomíná důsledný komparační a konfrontační přístup prof. Žaži ke zkoumaným jazykovým jevům a jeho prrínos mj. pro konstituování syntaktických teorií českých rusistů.

Sborník je důstojným připomenutím osobnosti profesora Stanislava Žaži, jeho prací, jeho odkazu. Ǩada př́spěvků na jeho bádání i prrímo navazuje. Uveřejněné stati nabízejí zajímavé podněty pro badatele v oblasti jazykovědné rusistiky a slavistiky a lze předpokládat, že se stanou inspirací pro další badatelskou činnost.

Marta Vágnerová

\title{
Bibliografie:
}

GAZDA, J. (ed.). (2020): Př́spěvky k aktuálním otázkám jazykovědné rusistiky (5): pragmatika - syntax - sémantika. Brno.

\section{Návraty k textologii a genezi textu}

ЩЕРБАКОВА, М.И. (ред.): От истории текста к истории литературы. Вып. 2. Москва: Институт мировой литературы им. А. М. Горького Российской академии наук, 2019. 408 с. ISBN 978-5-9208-0458-7.

V poslední době se objevila řadu náznaků i otevřených vyjádření vykazujících zjevné metodologicky podložené směřování $\mathrm{k}$ textologické a genetické analýze literárního textu. V širších souvislostech jsme se zmiňovali i o recenzované knize [POSPÍŠIL 
2020a]; jde vlastně o sborník mapující především ruskou literaturu 19. století, tedy ruskou klasiku „zlatého věku“.

Zvláštní obrat literární vědy poslední doby $\mathrm{k}$ historicitě, zkoumání geneze textu a $\mathrm{k}$ textologické analýze uměleckého textu spojuje tuto tendenci $\mathrm{s}$ reakcí na převažující funkčně synchronní pojetí první poloviny 20. století, na jeho odvrat od pozitivistické literární historie k rozostřování metodologie literární vědy a k rozšiřování jejího půdorysu směrem $\mathrm{k}$ aplikovanému a odvozenému výzkumu; to se ostatně projevuje $\mathrm{v}$ celé sféře filologie jako disciplíně, jež se zabývá jazykem a literaturou. V samostatných pojednáních, z nichž na jedno odkazuji níže, jsem na tyto obecné tendence $\mathrm{k}$ diachronii, genezi a historicitě upozornil. Jak jsem se tam zmínil, nakolik bude tendence trvalá a nakolik jde o rutinní vyrovnávání badatelské balance jako posílení faktografického a historického základu literární vědy nebo jen o dočasnou konjunkturální vlnu, ukáže až budoucnost.

Ve sféře literární teorie a historie se ke konci 10. let 21. století objevila řada nových publikací, které se cíleně zabývají genezí textů, tedy analýzou jejich historie a pramenného základu. Takovou knihou je sériová publikace moskevského Ústavu světové literatury A. M. Gorkého Ruské akademie věd s př́íznačným názvem Od historie textu $k$ historii literatury [ŠCERBAKOVA 2019]. Název přesně odpovídá tomu, co se nyní v některých odborných kruzích tolik zdůrazňuje: návrat historického př́stupu.

Příznačný je již úvod od redaktorky M. I. Ščerbakovové: „Текстология из неоправданно тесных рамок дисциплины, каковой считалась прежде, выросла и к концу $\mathrm{XX}$ века сформировалась как базовая научная отрасль знаний. Проводимые сегодня энергичные исследования в этой области подтверждают богатейший научный потенциал текстологии и востребованность ее открытий. Три столпа, на которых прочно стоит текстология - это история текста, творческая воля автора и научная критика текста [...] Изучение историко-литературных источников - титаническая исследовательская работа историков и филологов. Ее результаты в виде серьезных академических изданий обогащают современную науку.“ [ŠČERBAKOVA 2019, 5]. Neřekl bych př́mo takto, že tyto výzkumy primárně obohacují vědu: především jde o podobu textů, jež se vydávají a jejichž variabilita může čtenáře uvádět ve zmatek, pokud jde o změny zásadní a klíčové, nebo naopak upřesnit chápání díla ve směru, jenž je tradiční, v každém př́ípadě jde o služebnou funkci; nikoli náhodou je textologie pomocnou vědou, at už historie nebo filologie apod.

Autory sborníku, který je již druhým dílem edice [ŠČERBAKOVA 2015], jsou většinou pracovníci vydavatele, tedy moskevského Ústavu světové literatury A. M. Gorkého (IMLI). $Z$ tohoto hlediska je pozoruhodné, že de facto žádný z prríspěvků $v$ podstatě nemá srovnávací charakter: i když je zřejmé soustředění na text jako takový, postupy textologie mají přece pevný ráz a bylo by možné tyto postupy výrazněji srovnávat. 
Materiál pokrývá období od konce 18. po konec 19. století s určitým publikačním přesahem (některé texty, jak uvidíme, vyšly posthumně), tedy epochu, kterou bychom mohli nazvat ruskou literární klasikou nebo „zlatým věkem“.

$\mathrm{Na}$ čele stojí studie A. D. Ivinského (IMLI) Поэтичекое наследие М. Н. Муравьева: К истории текста ранних стихотворений. M. N. Muravjov (1757-1807) byl sice dobově nejen znám, ale také uznáván jako básník a dramatik, ale jeho dílo není dosud zcela poznáno a publikováno. To se autor pokouší napravit publikováním řady básnických textů, dokonce ve zvláštní príloze, a snaží se je edičně „ošetřit“, přičemž nás seznamuje s problémy jejich edice. Básně jsou ze 70.-80. let 18. století a jejich charakter je v podstatě klasicistický s typickými ohlasy (citáty, reminiscencemi, aluzemi) antiky; básně jsou věnovány také historickým osobnostem, jsou často dedikovány, jsou „státotvorné“, jak bylo u klasicistů běžné; nazývají se „poémy“ (поемa), najdeme tu i žánr sonetu (соннет), jiné mají satirický nádech, což je opět jeden ze znaků klasicismu, obsahují obecné úvahy (Мысли о времени), jinde najdeme i „poezii všedního dne“ blízkou rokokovému básnictví, např̀ v lyrickém čísle Povest два иль три, / Варили в деревнях, в Михайловщине пиво, / И люди добрые не ставили то в диво, / И кутали свои окошки из нутри." [ŠČERBAKOVA 2019, 44]. Jeho lyrika je v podstatě didaktická, dílem reflexivní, nikoli však přírodní a milostná, jak bývá zvykem u jeho sentimentalistických a později preromantických takřka současníků. Textologické zpracování a publikování lyrických básní M. N. Muravjova poněkud upravuje vývojovou trajektorii ruských literárních směrů - potvrzuje časté návraty a retardace a běžnou dlouhodobou symbiózu osvícenství, klasicismu, rokoka, sentimentalismu a preromantismu.

V.M. Jesipov (IMLI) na několika případech demonstruje ještě nevyřešené problémy textologie Puškinovy básnické tvorby, např. básně Поэmy (1830), šesté kapitoly Evžena Oněgina, epigramu na N. I. Gnědiče (Puškin básníka vždy chválil za překlad Iliady, ale v tomto epigramu ho nevybíravě napadl. Autor to vysvětluje ruským př́íslovím, které máme v jiné podobě i my: „Ради красного словца не пожалеешь и родного отца." (u nás: Pro dobrý vtip zabije i vlastní babičku). Gnědič měl od mládí postižení obličeje onemocnění neštovicemi; zkřivil se mu obličej a přišel o oko, takže se k partnerům natáčel tou „lepši“ částí tváře. Puškinovy verše: „Крив был Гнедич поэт, преложитель слепого Гомера, / Боком одним с образцом схож и его перевод.“ (Homér byl údajně slepý, i když někteří tvrdí, že slepota byla synonymem vizionářské schopnosti; Gnědič přišel o oko a měl křivý obličej). Puškin se prý později za epigram styděl a ani ho nikde nepublikoval, takže toto uveřejnění je vlastně první.

Podobně A. S. Fomičevová (Vserossijskij muzej A. S. Puškina v Sankt-Petěrburgu) zkoumá dvě redakce Puškinovy básně Два чувства дивно близки нам... Zajímavá je studie V. I. Korovina (Pedagogičeskij univerzitet, Moskva) o Lermontovově čítankové básni Выхожу один я на дорогу... Vrací se k známé analýze Borise Ejchenbauma, 
zmiňuje tematickou a žánrovou blízkost rané poezii F.I. Tjutčeva, jen tento dílčí závěr se mi nezdá přesný: „Лирический монолог „Выхожу один я на дорогу... дает основания усматривать в творчестве Лермонтова два фундаментальных и равноправных начала - протест, бунт, мятеж против устройства бытия, а также связанное с ним сознание безнадежности изменить земной мир, и смиренное приятие бытия в надежде обретения счастья в небесном царстве. Чем безнадежнее мысль о совершенстве земли, тем сильнее жажда блаженства за ее пределами.“ [ŠČERBAKOVA 2019, 110]. Jestliže závěrečné verše básně budeme chápat jako rozpuštění v př́rirodě, kdy si člověk i po smrti, která je vlastně jen jinou formou života, uchovává životní síly („Но не тем холодным сном могилы... / Я б желал навеки так заснуть, / Чтоб в груди дремали жизни силы, / Чтоб, дыша, вздымалась тихо грудь; // Чтоб всю ночь, весь день мой слух лелея, / Про любовь мне сладкий голос пел, / Надо мной чтоб, вечно зеленея, / Темный дуб склонялся и шумел...") jako panteismus, nebudeme asi hledat útěchu v nebi, ale přímo $\mathrm{v}$ tom, co tu je jako výsledek stvoření - ale to je vzhledem $\mathrm{k}$ tématu studie detail.

Přínosná se mi zdá analýza a publikování jediného zachovaného autografu Gogolovy novely Vij. Autorem je I. A. Vinogradov (IMLI). I. A. Zajcevová (IMLI) rozebírá textologické varianty známé „scény lhaní“ (сцена вранья) z Gogolova Revizora a ukazuje na její textovou genezi až k její konečné podobě, jež byla hrána a publikována („Один раз я даже управлял департаментом. И странно: директор уехал, куда уехал, неизвестно. Ну, натурально, пошли толки. Как, что, кому занять место? Многие из генералов находились охотники и брались, но подойдут, бывало нет, мудрено. Кажется и легко на вид, а рассмотреть - просто, черт возьми, видит, нечего делать - ко мне. И в ту же минуту по улицам курьеры, курьеры, курьеры, - можете представить себе, тридцать пять тысяч одних курьеров! Каково положение, я спрашиваю?“ [ŠČERBAKOVA 2019, 187]).

J. G. Paderina (IMLI) analyzuje textologické experimenty v edici poškozených autografů N. V. Gogola a konstatuje, že nutno někde určit hranici, za kterou při pokusech o obnovení a dotváření textu už jít nelze (eds: N. S. Tichonravov, V. I. Šenrok, I. I. Korobka, A. L. Slonimskij), i když souhlasí s tím, že edice je v podstatě úspěšná.

J.J.Dmitrijevová a A. A.Šolochovová (IMLI) pojednávají o historii publikace druhého dílu Mrtvých duši od údajné ztráty rukopisu až po jeho objevení a vydání (1855), Jádrem studie je však podrobné textologické komentování druhého dílu románu.

D. A. Badaljanová pojednává o knize I. S. Aksakova Биография Федора Ивановича Тютчева, a to о historii vzniku textu, cenzuře a jeho publikování. Cenzura se soustředila mimo jiné na charakteristiku samoděržaví (autokracie) nikoli jako na uzurpaci moci, ale jako na právo panovníka posvěcené souhlasem celé země, dané vlastně všenárodním konsensem s touto formou vlády. Vynikající je př́íspěvek 
A. G. Groděcké (Institut russkoj literatury / Puškinskij dom, Sankt-Peterburg) o vydání prvního dílu korespondence I. A. Gončarova s komentářem, přičemž se pozornost věnuje zvláště dopisům z proslulé cesty kolem světa na lodi Pallas/Pallada s pozdějším admirálem, hrabětem Jevfimijem Vasiljevičem Pưtatinem (1803-1883), která se stala tématem známého cestopisu Fregata Pallas/Pallada (Fregat Pallada, 1855-1858). M. A. Mjakinčenková (IMLI) zaujala již názvem své práce, která místo tradičního obratu „moskevský text“ používá tradiční „moskevské téma“ - jde o biografické prameny tohoto tématu v tvorbě F. M. Dostojevského. Narace mnicha Parfenije (Agejeva, 1855), vlastně vyprávění o cestě do Moldávie, Turecka a Svaté země, se stala jádrem hagiografického textového souboru kláštera známého jako Optina pustyň, místa návštěv a pobytů (domky, v nichž pobývali, se zachovaly dodnes) lékaře, diplomata a náboženského filozofa Konstantina Leontjeva, Nikolaje Gogola a Fjodora Dostojevského, kteří zde rozjímali, nebo, na druhé straně ve světské sféře, totiž v románu Dostojevského Běsi (1871-1872). V každém prrípadě šlo o emblematické, široce čtené, kultovní dílo, k němuž se vyjadřovali významní ruští spisovatelé, např. Apollon Grigor'jev, Ivan Turgeněv a další - využitím jednoho motivu ve zmíněném románu se však zapsalo do ruské literatury nejvýrazněji. Autorem studie na toto téma je V. V. Kaširinová (IMLI).

J. V. Belousovová (Muzej-usadba L. N. Tolstogo „Jasnaja Poljana“) analyzuje ústř̌ední „uměleckou myšlenku“ (?) novely spisovatelova staršího bratra Nikolaje Nikolajeviče Tolstého Пластун (označení př́íslušníka kozáckého vojska, obvykle dobrého střelce určeného ke strážní nebo výzvědné službě), zajímavá paralela k volné trilogii jeho bratra Dětství (Детство, 1852), Chlapectví (Ompoчecmвo, 1852-1854), finošství (Юность, 1855-1857) - jde zejména o mravní konflikt, spor mezi náboženskými zásadami a charakterem praktického, světského života, tedy to, co zajímalo po celý život a v podstatě v každém jeho díle i velkého romanopisce. Nikolaj Nikolajevič Tolstoj (1823 Jasnaja Poljana - 1860 Bad Soden u Frankfurtu nad Mohanem) byl talentovaný prozaik, ale životní osudy ho nedovedly k vrcholům jako jeho bratra (na rozdíl od něho však úspěšně absolvoval Kazaňskou univerzitu). Пластун vyšel až radu let po jeho smrti roku 1926. Jakoby okrajové didaktické dílo jeho bratra Lva Azbuka (1871-1872) je tématem studie J. V. Nikolajevové (Pedagogická univerzita v Moskvě). N. I. Romanovová (IMLI) se zaměřuje na scénu návratu Anny Kareninové do Petěrburgu ve vztahu ke genezi textu románu. U Anny Kareninové setrvává i Antonella Cavazza z univerzity v italském Urbinu, která z filologického hlediska traktyŭe téma smrti (jinak jde o téma v tolstojologii tradiční). I. I. Sizovovová (IMLI) se zabývá textologickými problémy dramatizace legendy o caru Haggaiovi (Легенда о ицаре Агzее) z pera L. N. Tolstého. M. A. Možarovová (IMLI) se podívala na historii rukopisů celého románu Anna Kareninová (1875-1877). M. I. Ščerbakovová (IMLI) se v práci př́íznačně nazvané Служение гению zabývala textologickou činností L. D. Gromovové-Opul'ské 
na př́ípravě vydání prvních dílů stodílných Sebraných spisů L. N. Tolstého; touto statí se cluster statí o L. N. Tolstém uzavírá.

Přesahem k hraběti Tolstému je ještě módní sousloví „tolstojovský text“, které se vrací ve stati A. A. Fedotovové (Pedagogická univerzita v Jaroslavli), účastnice brněnských doktorských škol, o novele N.S. Leskova Slzavé údolí (Юдоль, 1892), ale zde si nejsem jist, zda jde skutečně hlavně o působení Tolstého: praktičnost, tolerance $\mathrm{k}$ jiným náboženstvím, a zájem o ně byly typické spíše pro Leskova než pro slavného romanopisce; $v$ tom byl Leskov asi hodně samostatný (ostatně o vztahu L. N. Tolstého a N.S. Leskova bylo už mnoho napsáno, jistěže je tam určitá paralela ${ }^{1}$ ). N. J. Danilovová (Leningradská státní univerzita A. S. Puškina), také účastnice brněnských doktorských škol, analyzuje rukopis Leskovovy románové kroniky Soumrak knížecího rodu (atraktivizující název českého překladu z pera Naděždy Slabihoudové; spíše však Zchudlý rod, orig. Захудальıй pod, 1874); A. A. Šelajevovová (Univerzita Sankt-Petěrburg), třetí účastnice brněnských doktorských škol, pojednala o pozapomenuté Leskovově novele Uražená Neteta (Оскорбленная Нетета, 1891-1892, publ. posthumně 1917, 1991), hledá její textové prameny (snad Josephus Flavius, ale i jiné), ale byl bych tu spíše skeptický, když je všeobecně známo, jak Leskov mystifikoval, pokud jde právě o genezi jeho próz. Z Flavia (Iosephus Flavius, asi 37-100 n.1., původním jménem Josef ben Matitjahu) jde o Židovské starožitnosti (Iúdaiké archaiologiá, lat. Antiquitates Iudaicae, ruské vydání Древности Июдейские. При Императорской академии наук, Санкт-Петербург 1795).

Snad lze uvést, že trojice leskovovských studií je dokladem vzrůstající důležitosti díla ruského klasika, dříve opomíjeného, také však důsledkem dosud nezpracovaného textového dědictví autora (Anna Fedotovová přispěla do prvního brněnského publikačního výstupu z doktorské školy statí Поэтика исторических очерков Н. С. Лескова, Alla Šelajevová napsala pro týž sborník studii Люди и кукль Н. С. Лескова в свете мифологических представлений о Боге и человеке [POSPÍŠIL 2018], N. J. Danilovová přispěla do druhého sborníku studií na podobné téma jako v recenzovaném sborníku [POSPÍŠIL 202ob]).

Recenzovaný svazek obsahuje různorodý materiál, jsou zde také různé metodologické přístupy, něco je nezpochybnitelné, něco je sporné, přítomné texty si jistě zaslouží zevrubnější analýzu textologa. Nás v daném případě zajímalo hlavně to, co naznačuje název obou svazků organizovaných moskevským Ústavem světové literatury: od historie textu k historii literatury. Nemyslím, že se uváděné textologické analýzy zásadně podepsaly na jiném chápání ruské literární klasiky, ale s textologií je to jako s proslulým latinským okřídleným citátem o kapce, která vyhloubí kámen

1 [N. S. Leskov... 2020]. Sama A. A. Fedotovová má na toto téma řadu statí, další odkazy: [REMIZOV 2020]. 
nikoli silou, ale častým dopadáním (gutta cavat lapidem non vi, sed saepe cadendo, citát z Ovidiových Epistulae ex Ponto). Snad je tu zajímavé i to, co výzkumný tým považuje ze "zlatého věku“ ruské literatury z hlediska textologie a geneze textu za stěžejní: stálicí jsou Puškin a Gogol, méně Dostojevskij, nejsou tu však ani Čechov nebo Turgeněv, ale hlavně tu jsou zastoupeni L. N. Tolstoj a N.S. Leskov - to je zajímavý, ale možná ne zcela záměrný, snad spíše náhodný posun.

Ivo Pospíšil

\section{Bibliografie:}

N.S.Leskov, L.N. Tolstoj.Perepiska. <http://az.lib.ru/t/tolstoj_lew_nikolaewich/text_ 0340.shtml.> [online]. [cit. 23. 8. 2020].

POSPÍŠIL, I. (ed.). (2018): Leskov i vokrug. Konteksty tvorčestva i sostojanije sovremennogo leskovovedenija. Brno.

POSPÍŠIL, I. (2020a): Ad fontes: geneze literárního textu jako svébytný návrat $k$ filologii. Philologia Rossica. 〈V tisku.

POSPÍŠIL, I. (ed.). (202ob): N. S. Leskov i tradicija russkogo romana v mirovom kontekste. Brno.

REMIZOV, V. B. (2020): Tolstoj i russkaja literatura. <https://www.tsput.ru/res/other/ Tolstoy/Literature/leskov.htm.> [online]. [cit. 23. 8. 2020].

ŠČERBAKOVA, M. I. (red.). (2015): Ot istorii teksta $k$ istorii literatury. Moskva.

ŠČERBAKOVA, M. I. (red.). (2019): Ot istorii teksta k istorii literatury. Moskva.

https://doi.org/10.5817/NR2020-2-9

\section{Когда слова могут оказаться нашими врагами...}

GRIGORJANOVÁ, T., GAJARSKÝ, L.: Slovník rusko-slovenských medzijazykových homoným. Brno: Tribun EU, 2019. 126 s. ISBN 978-80-263-1544-5.

Межъязыковые омонимы опасны не только для переводчиков, но и для всех изучающих иностранные языки. В основном это явление наблюдается в близкородственных языках. Каждый, кто изучал или изучает такой язык, наверное, попадал в ситуацию, когда что-то неправильно понял из-за сходства слов. Ему либо не хотелось искать перевод, либо просто у него не было доступа к словарю, чтобы узнать значение слова. Такие ситуации чаще всего бывают смешными, но иногда могут оказаться весьма неприятными или 